\title{
ETOS BELAJAR SISWA SEKOLAH DI DAERAH PINGGIRAN
}

\author{
S. Bayu Wahyono, Deni Hardianto, dan Unik Ambarwati \\ Universitas Negeri Yogyakarta \\ Email: bayu_wahyono@yahoo.com
}

\begin{abstract}
Abstrak
Penelitian ini bertujuan ingin mengetahui dan menganalisis penyebab rendahnya etos belajar siswa dari perspektif sosial budaya, dan menawarkan solusi yang efektif bagi upaya meningkatkan etos belajar siswa di daerah pinggiran. Pilihan metode penelitian adalah metode survei dan penelitian kancah (field research). Hasil penelitian menunjukan bahwa etos belajar siswa Sekolah Menengah Atas/Kejuruan (SMA/SMK) di daerah pinggiran ternyata masih dalam kategori sedang cenderung rendah. Indikatornya adalah bahwa dikalangan siswa sekolah pinggiran ditandai rendahnya minat baca, kurang menyukai tantangan atau rendahnya watak kompetitif, rendahnya kemandirian, tanggung jawab belajar yang tidak tinggi. Letak teritorial cenderung memiliki hubungan signifikan terhadap rendahnya etos belajar siswa di sekolah pinggiran dan terdapat hubungan yang tidak linier antara persepsi positif terhadap belajar dengan praksis belajar di kalangan siswa sekolah daerah pinggiran.
\end{abstract}

Kata kunci: etos belajar, daerah pinggiran

\section{LEARNING SPIRIT OF STUDENTS AT RURAL AREAS}

\begin{abstract}
The aims of this study are to find and to analyze the causes of students' low learning ethos from the socio-cultural perspectives and to offer an effective solution for improving the learning ethos of students in the suburban areas. This was a survey study and field research. The findings show that the learning ethos of Senior/Vocational High Schools in the suburban areas were still in the moderate and tend to be in the low category. The indicators were the students' low reading interest, they did not like challenges or they are lack of competitive character, lack of autonomy and they did not fell that they have a learning responsibility. The territorial position tends to contribute to the low learning ethos of the students in the suburban schools and there was no linear connection between the positive perception of learning and the learning practice of students in the suburban areas.
\end{abstract}

Keywords: learning ethos, suburban areas

\section{PENDAHULUAN}

Pemerintah terus mengupayakan peningkatan kualitas pelayanan pendidikan sebagai bagian dari kewajiban konstitusionalnya. Sebagaimana amanat konstitusi yang tercantum dalam pasal 31 UUD 1945, setiap warga negara pada prinsipnya harus mendapatkan pendidikan yang layak. Jadi setiap warga negara memiliki hak untuk mendapatkan pelayanan pendidikan yang memadai, tidak terkecuali warga negara yang secara teritorial berada di daerah pinggiran, seperti di pedesaan, atau pun yang berada di daerah pelosok serta terpencil.

Melalui serangkaian kebijakan yang bernuansa pemerataan pendidikan seperti pencanangan program Wajib Belajar 
6 dan 9 tahun, bahkan dalam waktu dekat Wajib Belajar 12 tahun, merupakan bukti komitmen pemerintah untuk meningkatkan pelayanan pendidikan kepada warga. Dengan kata lain, pemerintah telah membuka kesempatan belajar bagi warganya, minimal lulus SMP sederajat, dan bahkan SMA sederajat. Pelaksanaan Wajib Belajar 9 tahun ini terus ditingkatkan, dan sekaligus dibarengi pemberian subsidi pendidikan dengan meluncurkan program Bantuan Operasional Sekolah, atau yang populer dengan akronim BOS. Di bidang prasarana-sarana juga terus diberikan baik dalam bentuk bangunan fisik dan renovasi gedung sekolah, peralatan laboratorium, alat peraga, buku paket, dan saranan penunjang lainnya. Bersamaan dengan itu, monitoring dan evaluasi terhadap proses pembelajaran juga terus dilakukan untuk menjaga kualitas layanan pembelajaran. Sumber Daya Manusia juga terus dikembangkan dengan memberikan biasiswa bagi guru untuk menempuh jenjang pendidikan yang lebih tinggi.

Pencapaian target kuantitatif hingga kini sudah cukup menggembirakan. Pada saat ini 94,7\% penduduk Indonesia berhasil mengenyam sekolah dasar, dan angka ini terus mengalami pertumbuhan positif. Namun angka partisipasi di tingkat SMP hanya bergerak perlahan dari $41,9 \%$ pada tahun 1990, saat ini hanya berada di posisi $66,5 \%$ dari target $100 \%$ seluruh penduduk mengenyam pendidikan hingga SMP pada tahun 2015. Sebagaimana ditetapkan dalam tujuan Milenium Develepment Goals (MDGs) ke 2, yakni Ketidaksetaraan akses pendidikan dan latihan memiliki 3 indikator, yaitu: 1. Partisipasi di tingkat SD dan SMP, 2. Proporsi murid yang bersekolah hingga kelas 5 dan tamat SD, 3. Melek huruf usia 15-24 tahun. Secara umum gambaran angka partisipasi murni (APM) di tingkat SD belum sungguh-sungguh mengalami progress yang terus positif, melainkan mengalami fluktuasi dalam 3 tahun terakhir.
Di Wilayah provinsi DIY, pergerakan positif menuju target MDGs ini juga terjadi, khususnya pada tingkat sekolah dasar, sedangkan pada tingkat SMP pergerakannya melambat. Kota Jogja dan Kabupaten Sleman APM mengalami kenaikan positif, sedangkan di kabupaten Bantul mengalami trend naik turun. Kondisi serupa juga terjadi untuk angka partisipasi murni tingkat SMP/MTS (13-15 tahun). Angka APM SMP mengalami peningkatan dengan trend fluktuatif. Upaya keras masih dibutuhkan untuk mencapai target 100\% seluruh penduduk Indonesia bersekolah hingga jenjang SMP. Terlebih terkait partisipasi anak perempuan yang rasio partisipasinya lebih kecil dari anak laki-laki. Kondisi ini menunjukkan profil pendidikan di Indonesia, dimana makin tinggi jenjang pendidikan, makin rendah angka partisipasi perempuan.

Akan tetapi permasalahan pemerataan pendidikan secara empirik masih tetap fenomenal, yang ditandai misalnya dengan semakin rendahnya kualitas pendidikan di daerah pinggiran. Ada kecenderungan bahwa prestasi siswa di sekolah-sekolah daerah pinggiran tidak sebaik pencapaian prestasi belajar di daerah pusat, yang kebanyakan di perkotaan. Meskipun tingkat kelulusan relatif tidak ada perbedaan signifikan antara siswa di sekolah pinggiran dengan yang di pusat, tetapi secara kualitatif tetap menyodorkan fakta bahwa tingkat pencapaian angka UN siswa di daerah pinggiran misalnya, lebih rendah daripada pencapaian UN siswa di perkotaan.

Salah satu sebab mengapa tingkat pencapaian prestasi belajar siswa di daerah pinggiran kurang memadai, antara lain adalah rendahnya etos belajar siswa di pedesaan. Etos itu sendiri mengandung pengertian beragam. Etos berasal dari bahasa yunani ethos yakni karakter, cara hidup, kebiasaan seseorang, motivasi atau tujuan moral seseorang serta pandangan dunia mereka, yakni gambaran, cara bertindak ataupun gagasan yang paling kom- 
prehensif mengenai tatanan. Dengan kata lain etos adalah aspek evaluatif sebagai sikap mendasar terhadap diri dan dunia mereka yang direfleksikan dalam kehidupannya (Dede Rosyada, 2004:8).

Menurut kamus Webster, etos didefinisikan sebagai keyakinan yang berfungsi sebagai panduan tingkah laku bagi seseorang, sekelompok, atau sebuah institusi (guiding beliefs of a person, group or institution).

Sementara itu belajar mengandung pengertian yang beragam juga. Berbagai ahli telah mencoba merumuskan pengertian belajar yang dilihat dari berbagai perspektif. Perspektif behaviorisme mengartikan belajar sebagai sebuah proses organism memperoleh bentuk perubahan perilaku yang cendrung terus mempengaruhi model perilaku umum menuju pada sebuah peningkatan. Perubhan perilaku tersebut terdiri dari berbagai proses modifikasi menuju bentuk permanen, dan terjadi dalam aspek perbuatan, berpikir, sikap, dan perasaan. Akhirnya dapat dikatakan bahwa belajar itu tiada lain adalah memperoleh berbagai pengalaman baru (Kochhar, 1967:27).

Kondisi lingkungan sosial budaya yang kurang menunjang semangat belajar seperti kondisi kemiskinan dan berkembangnya persepsi bahwa sekolah tidak mengubah nasib, menyebabkan siswa di daerah pinggiran kurang antusias belajar. Di samping itu, tingkat kompetisi yang rendah di antara siswa dalam mencapai prestasi belajar, juga menjadi kendala mengapa mereka rendah motivasi belajarnya. Faktor struktural dan kultural ini berpotensi menjadi kendala bagi siswa di daerah pinggiran dalan usahanya meningkatkan etos belajar. Bahkan dapat diduga bahwa aspek sosial budaya masih menjadi penyebab tidak tumbuhnya etos belajar siswa. Asumsi ini diperkuat ketika sarana, kurikulum, guru, dan sarana penunjang sudah relatif sama antara sekolah di pinggiran dengan di perkotaan, maka penyebab rendahnya prestasi belajar dapat disebabkan di luar faktor tersebut, yaitu oleh rendahnya etos belajar siswa.

Sementara itu secara kultural, pandangan dunia warga masyarakat pinggiran terhadap dunia sekitarnya juga memberikan pengaruh signifikan terhadap makna bersekolah dan makna belajar. Selama ini telah berkembang persepsi bahwa untuk apa sekolah dan giat belajar, pada kenyataannya tidak mampu mengangkat status sosial. Mereka dengan menempuh pendidikan, tetap saja tidak keluar dari kondisi hidup yang terjerat kemiskinan. Warga daerah pinggiran, terutama di daerah pedesaan masih didominasi cara berpikir fatalistik, mereka miskin karena memang ditakdirkan menjadi orang miskin dan tertinggal. Oleh karena itu mereka beranggapan, untuk apa giat belajar jika pada kenyataannya mereka tetap saja miskin. Kondisi hidup warga pinggiran yang miskin berhubungan dengan kemalasan belajar.

Berangkat dari isu dan permasalahan pendidikan di DIY tersebut, maka sebagai upaya peningkatan kualitas pendidikan secara merata, perlu meningkatkan etos belajar siswa. Usaha ini akan bermanfaat bagi upaya menyusun pemetaan kualitas pendidikan, sehingga akan dapat digunakan sebagai menyusun kebijakan strategis pemerintah dalam meningkatan pelayanan pendidikan pada masyarakat.

Pertanyaan utama yang akan dijawab dalam penelitian ini adalah bagaimana etos belajar siswa pada setiap sekolah jenjang SMA/sederajat baik negeri maupun swasta di daerah pinggiran DIY; faktorfaktor apa saja yang berkaitan dengan rendahnya etos belajar siswa di sekolah pinggiran; dan bagaimana upaya sekolah untuk meningkatkan etos belajar siswa. Adapun tujuan penelitian ini adalah mengetahui dan menganalisis penyebab rendahnya etos belajar siswa; mengetahui komitmen sekolah dalam usaha mengatasi rendahnya etos belajar siswa; dan menawarkan solusi 
yang efektif bagi upaya meningkatkan etos belajar siswa di daerah pinggiran.

\section{METODE}

Penelitian ini menggunakan kombinasi metode survei dan penelitian kancah (field research). Metode survei digunakan untuk mengumpulkan data-data primer dari pengalaman dan pendapat responden melalui angket dan interview guide, di mana analisis menggunakan model kuantitatif dengan menerapkan statistik deskriptif. Penelitian kancah dilakukan untuk mendapatkan berbagai data (pernyataan, perilaku, dan kejadian di kalangan siswa) kualitatif lapangan yang berlangsung di sekitar responden dengan observasi dan wawancara, serta analisis melalui pemahamahan secara interpretatif. Namun dalam penelitian ini wawancara belum dilakukan secara mendalam, karena keterbatasan waktu.

Penelitian ini mengambil populasi siswa SMA/SMK di DIY. Ada empat kabupaten/kota yang ada di Propinsi Daerah Istimewa Yogyakarta (DIY) seluruhnya dipilih menjadi wilayah sampel penelitian ini, yakni; Kab. Bantul, Kab. Gunung Kidul, Kab. Sleman, dan Kab. Kulonprogo. Setiap kabupaten/kota dipilih 2 sekolah yang memiliki salah satu kriteria sebagai berikut: (1) sekolah memiliki akses yang cukup jauh dari pusat kota kabupaten dilihat dari letak geografis; (2) sekolah negeri yang kurang maju di daerah pinggiran kabupaten; dan (3) sekolah swasta yang kurang maju di daerah pinggiran kabupaten

Berdasarkan kriteria tersebut, maka lokasi penelitian pada tingkat kecamatan ditetapkan sebagai berikut:

Tabel 1. Kabupaten dan Kecamatan Lokasi Penelitian

\begin{tabular}{ll}
\hline \multicolumn{1}{c}{ Kabupaten } & \multicolumn{1}{c}{ Kecamatan } \\
\hline Kabupaten Bantul & Srandakan dan Piyungan \\
Kabupaten Gunung Kidul & Rongkop \\
Kabupaten Kulonprogo & Galur \\
Kabupaten Sleman & Ngemplak \\
\hline
\end{tabular}

Subyek dalam penelitian ini adalah siswa SMA/SMK yang berjumlah 92 siswa. Semula dalam penelitian ini ditetapkan jumlah subyek cukup banyak yaitu 96 siswa, dengan ketentuan masing-masing kabupaten diwakili oleh 2 SMK yaitu satu sekolah swasta dan satu sekolah negeri. Setiap sekolah akan diambil sample secara acak terdiri dari 4 siswa kelas 1, 4 siswa kelas 2 dan 4 siswa kelas 3 sehingga setiap sekolah diwakili oleh 12 siswa.

\section{HASIL DAN PEMBAHASAN}

Berikut akan diuraikan data hasil penelitian berkaiatan dengan etos belajar. Salah satu pertanyaan penting yang diajukan dalam riset ini adalah bagaimana etos belajar siswa sekolah di daerah pinggiran. Karena itu penelitian ini ingin menjawab bagaimana etos belajar siswa sekolah daerah pinggiran di Provinsi DIY. Beberapa argumen menjadi dasar dari rumusan masalah tersebut, antara lain apakah makin ke pinggir etos belajar siswa makin rendah mengikuti garis konsentris model kekuasaan Jawa? Atau setidaknya, apakah model pembangunan pendidikan sentralistik yang diterapkan secara efektif pada era Orde Baru, masih memiliki implikasi terhadap kondisi belajar siswa di pinggiran? Jika hasil penelitian ini pararel dengan tesis tersebut, kiranya menarik untuk menggali dan menganalisis faktor-faktor penyebab berlakunya tesis tersebut di tengah arus demokratisasi pendidikan.

Setelah melakukan pengolahan data lapangan, riset ini memperoleh informasi data sebagaimana tergambar dalam diagram berikut.

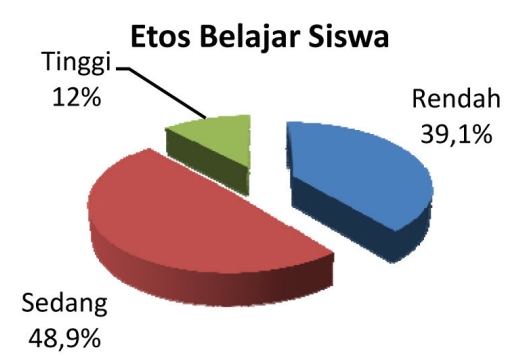

Gambar 1. Etos Belajar Siswa SMA/SMK 
Gambar 1 menginformasikan bahwa etos belajar siswa sekolah di daerah pinggiran secara umum dapat dikatakan rendah, atau jika dikuantifikasi angkanya mencapai 39,1 persen rendah, 48,9 persen kategori sedang, dan hanya 12 persen yang masuk kategori beretos tinggi. Kuantifikasi itu merupakan uraian dari beberapa indikator etos belajar, yang meliputi minatbaca, tanggungjawab, kemandirian, dan keberanian menghadapi tantangan dalam proses belajar. Apabila diuraikan secara rinci maka ilustrasi etos belajar siswa sekolah pinggiran akan tergambar dalam beberapa tabel berikut.

\section{Minat Baca}

Dalam hal minat baca misalnya, ratarata responden siswa sekolah pinggiran masih rendah. Ketika ditanya kegiatan apa yang paling menyita waktu di luar sekolah hanya 23,9 persen yang mengaku membaca dan mengerjakan pekerjaan rumah (PR) sekolah. Sementara yang mengaku bermain dengan teman 28,3 persen, menonton televisi 17,4 persen, dan membantu pekerjaan orangtua mencari nafkah sebesar 26,1 persen. Untuk aktivitas terakhir itu memang mengandung muatan pendidikan, karena bagaimanapun kegiatan membantu pekerjaan orangtua mencari nafkah adalah baik secara edukatif. Akan tetapi kondisi sosial ekonomi warga masyarakat pinggiran seperti itu sedikit banyak tentu berpengaruh terhadap semangat belajarnya.

Sementara itu bermain dengan teman menunjukkan angka tertinggi yaitu 28,3 persen. Situasi itu mengindikasikan bahwa aktivitas bermain masih mendominasi kegiatan siswa sehabis pulang sekolah. Untuk ukuran siswa setingkat SMA adalah bukan waktunya lagi bermain seperti usia prasekolah yang aktivitas utamanya memang harus bermain. Jadi jika bermain atau dalam bahasa Jawa dolan, tetap menjadi kegiatan utama siswa di daerah pinggiran, adalah indikasi yang kurang baik bagi etos belajar. Sekarang ini memang cukup banyak terlihat aktivitas anak usia sekolah lanjut yang kurang mampu memanfaatkan waktu untuk mendukung kegiatan belajarnya. Di desa-desa banyak sekali anak-anak muda yang hanya nongkrong dan kongko-kongko di pinggir jalan, di bengkel-bengkel motor, di tempat-tempat teduh, yang hanya ngobrol membuangbuang waktu.

Situasi itu semakin kurang baik, ketika responden mengaku menonton televisi merupakan aktivitas keseharian setelah pulang sekolah. Sebanyak 17,4 persen yang mengaku menonton televisi sebagai kegiatan utama setelah pulang sekolah. Jadi budaya baca belum tumbuh dengan baik, sementara budaya menonton lebih berkembang yang ditunjukkan pada aktivitas menonton televisi. Media televisi memang sudah menjadi bagian yang penting dalam aktivitas sehari-hari di desadesa. Hampir dipastikan tidak ada satu pun rumah tangga yang tidak memiliki pesawat televisi di DIY. Karena itu televisi adalah salah satu media yang sangat potensial dalam mengurangi jam belajar siswa setelah pulang sekolah. Untuk lebih detail bisa dilihat dalam tabel berikut.

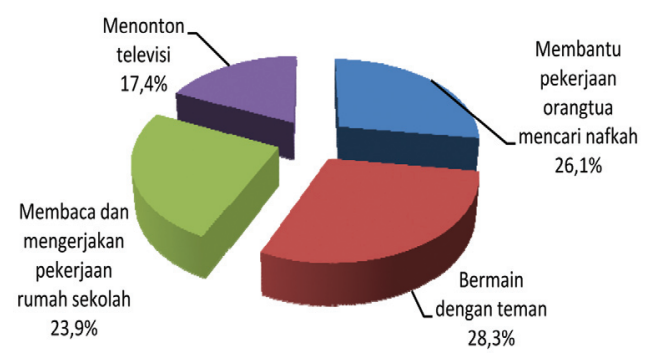

Gambar 2. Kegiatan yang Paling Menyita Waktu

Memperhatikan Gambar 2 menunjukkan bahwa aktivitas pendukung belajar setelah pulang sekolah masih didominasi oleh kegiatan yang kurang ada relevansinya dengan belajar. Oleh karena itu dapat dipahami jika etos belajar siswa di sekolah pinggiran masih masuk dalam kategori rendah. 


\section{Tanggung Jawab}

Sementara itu, rendahnya etos belajar juga dapat dilihat pada seberapa besar sikap bertanggung jawab terhadap tugas yang diberikan oleh sekolah. Tanggung jawab ini dilihat dari tingkat kecepatan mengerjakan tugas yang berkaitan dengan pelajaran dengan waktu 1 jam; tingkat kecepatan pemahaman terhadap pengetahuan baru; dan sikap yang berkembang ketika mendapat penugasan di seputar pelajaran sekolah. Tingkat tanggungjawab siswa sekolah pinggiran ternyata dapat dikatakan cenderung sedang bergerak ke rendah, yaitu 32,6 persen kategori rendah, 47,8 kategori tinggi, dan sementara hanya 19,6 kategori tinggi.

Jadi ketika diberi tugas yang berkaitan mata pelajaran dengan waktu 1 jam, kebanyakan siswa menghabiskan waktu satu jam, dan bahkan ada yang tidak selesai. Sedangkan ketika mendapat pengalaman baru dalam belajar sesuatu yang memerlukan waktu sekitar satu jam, mereka ratarata mengaku satu jam pula dan bahkan ada yang lebih dalam kemampuan memahaminya. Sementara itu ketika mendapat tugas sekolah dalam kaitannya dengan belajar, siswa kebanyakan mengaku mengerjakan tetapi ada yang belum selesai, dan ada pula yang mengaku kadang-kadang mengerjakan. Bahkan ada yang mengaku sering tidak mengerjakannya, dan hanya beberapa responden yang mengaku selalu mengerjakan tugas sampai tuntas. Atau secara lebih rinci dapat diperiksa dalam tabel berikut.

Tabel 2. Tanggung Jawab terhadap Tugas Belajar

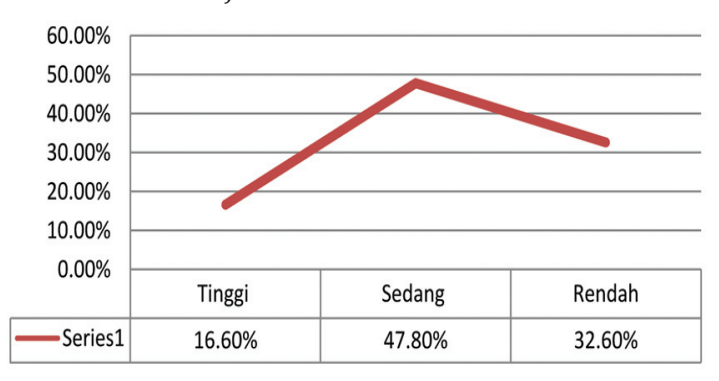

\section{Keberanian Menghadapi Tantangan}

Dalam kaitannya dengan sikap dan pandangan terhadap tantangan, secara umum siswa sekolah pinggiran kurang menyukai tantangan belajar. Beberapa item yang menunjukkan kurangnya menyukai tantangan antara lain yang berkaitan dengan dorongan mencari pengalaman baru, antusiasme mengerjakan tugas di depan kelas, keterikan terhadap tugas yang berisiko tinggi, keberanian bertanya pada guru dalam kelas, dan ketertarikan terhadap aktivitas kontestatif.

Ketika ditanya apakah suka mencari pengalaman baru rata-rata siswa mengaku kadang rata-rata menjawab hanya kadangkadang. Sangat sedikit yang mengaku bahwa menjadi siswa harus mendapat pengalaman baru. Bahkan ada yang mengaku kurang tertarik mencari pengalaman baru, yang penting belajar hanya mengikuti kegiatan begitu saja secara rutin. Ketika diberi tugas oleh guru di depan kelas rata-rata kurang percaya diri. Siswa sekolah pinggiran kebanyakan mengaku grogi dan muncul perasaan takut, sementara yang mengaku sangat antusias dan bersemangat hanya sedikit. Siswa pinggiran juga kurang kurang tertarik terhadap tugas yang sulit dan berisiko tinggi. Boleh jadi ini merupakan implikasi logis dari kultur agraris-tradisional yang kurang berani mengambil risiko karena hanya ingin sesuatu yang sudah pasti, sekalipun itu hanya soal keuntungan yang minimal.

Satu indikator lain ketidaksukaan terhadap tantangan pada kalangan siswa di sekolah pinggiran juga tercermin pada kebiasaan bertanya dalam kelas. Kebanyakan siswa mengaku hanya kadang-kadang mengajukan pertanyaan, dan bahkan cenderung jarang sekali mengajukan pertanyaan, serta ada pula yang mengaku sama sekali tidak pernah bertanya jika mengikuti pelajaran di kelas. Keengganan bertanya itu berbanding lurus dengan "kultur diam" yang berkembang dalam 
masyarakat pedesaan yang merupakan masyarakat pinggiran. Dalam masyarakat patrimonialistik kultur bertanya memang sulit berkembang, karena segala sesuatu mengalir dari secara vertikal. Jarang sekali muncul tradisi dialog dalam suatu masyarakat yang memiliki struktur sosial berkarakter hierarkis atau nonegalitarian. Karakter kultural semacam itu tercermin pula dalam proses belajar di sekolah, sehingga guru senantiasa dalam posisi sentral. Meskipun sudah diintrodusir metode belajar yang mengutamakan peran siswa aktif seperti student center, tetapi teaches center masih tetap mendominasi. Posisi guru yang begitu sentral mengkondisikan suasana belajar yang kurang dialogis, dan karena itu kurang merangsang tumbuhnya minat bertanya di kalangan siswa. Situasinya tetap guru yang mengambil peran aktif, sementara siswa kurang antusias dalam bertanya yang menghidupkan suasana kelas dalam belajar. Gambaran kurang antusiasnya siswa sekolah pinggiran dalam bertanya dalam kelas adalah sebagai berikut.

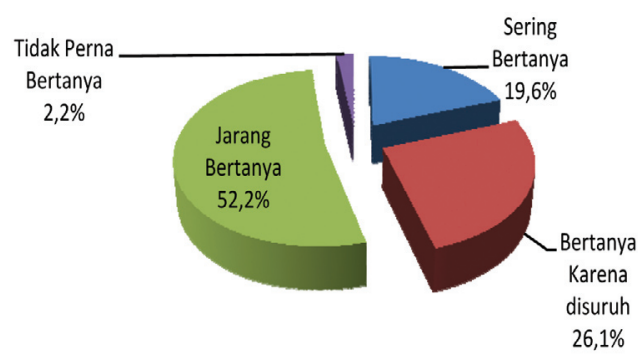

Gambar 3. Intensitas Bertanya Kepada Guru

Dalam gambar 3 menginformasikan bahwa hanya 19,6 persen siswa sekolah di daerah pinggiran yang mengaku sering bertanya kepada guru ketika mengikuti pelajaran di kelas, dan hanya 26,1 persen mengakui ketika bertanya karena disuruh guru. Sementara itu sebanyak 52,2 persen mengaku jarang sekali bertanya, dan bahkan 2,2 persen mengaku sama sekali tidak pernah bertanya. Fakta itu mengindikasikan bahwa betapa persoalan bertanya masih belum menjadi budaya di kalangan siswa, sehingga sudah dapat diduga bahwa tingkat keaktifan dalam kelas relatif rendah. Tentu saja semua itu pun belum dilihat secara kualitatif, dalam arti kualitas bertanyaan siswa itu seberapa kadar relevansinya dan apakah pertanyaan itu berbobot. Sering kali pertanyaan siswa kurang berbobot karena hanya bersifat teknis, bukan pertanyaan konseptual. Salah satu sebabnya adalah bahwa siswa sering kurang menguasai konseptualisasi inti pelajaran, dan hanya menghafalkan definisi sebuah pengetahuan. Bahkan tidak jarang, kemampuan guru terhadap pengetahuan konseptualistik juga kurang, sehingga guru pun sering dan bahkan menyenangi terhadap materi pelajaran yang hanya bersifat definitif. Model pembelajaran seperti itu adalah model khas di Indonesia yang bercorak mendisiplinkan pikiran, sehingga tidak mungkin mengembangkan daya imajinasi dan kreativitas berpikir siswa.

Boleh jadi ini juga ada kaitannya dengan maraknya metode belajar yang lebih bernuansa teachers center, top-down, dan mendikte. Ada semacam arus penyeragaman yang merasuk dalan pluralisme masyarakat, merambah kemana-mana pada segala aspek kehidupan. Dalam dunia pendidikan, apabila dicermati secara lebih mendalam, fenomena penyeragaman itu sebenarnya sudah berlangsung lama. Semua merasakan betapa anak didik kita dewasa ini selalu dibiasakan serba seragam. Sejak dari TK hingga sekolah menengah umum mereka diharuskan memakai seragam, baju, celana, topi, ikat pinggang, sampai kaos kaki. Lebih dari itu kurikulum pun diseragamkan, termasuk juga cara mengajarnya mesti seragam.

Repotnya arus penyeragaman itu tidak saja yang bersifat fisik, melainkan sampai pada penyeragaman pikiran dan bahkan tingkah laku. Diciptakan kondisi sedemikian rupa sehingga murid dan bahkan 
mahasiswa tidak punya peluang berpikir lain dari pada yang diajarkan guru. Akibatnya pluralisme berpikir menjadi lenyap.

Sementara guru sendiri tidak bisa menolak, Karena mereka hanya melaksanakan tugas dan kurang diberi peluang untuk mengembangkan metode mengajar secara otonom, karena metodenya harus seragam sebagaimana yang diinstruksikan oleh birokrasi pendidikan. Demikian pula alat evaluasi pun mesti seragam yang mewujud dalam Ebtanas. Guru tidak punya kesempatan untuk mengembangkan alat evaluasi pengajaran yang sesuai dengan kondisi permasalahan yang dihadapi di lapangan.

Birokrasi pendidikan yang mengkondisikan guru untuk memilih metode mengajar yang menghendaki murid serba nurut. Akibatnya anak didik kita pun tibatiba menjadi penurut yang setia. Ruang kelas bukan tempat pencerahan bagi murid, melainkan sering menjadi tempat dimana pemikiran kritis dikikis. Para siswa dan juga mahasiswa sering kali di drill jadi mesin hapalan. Yang lebih dominan bukan diajari bagaimana berpikir logis, kritis, dan kreatif, melainkan diajari menghapal dan meyerap informasi sebanyak-banyaknya tanpa keharusan bagaimana mengolah informasi itu.

Bukan berarti guru tidak menyadari bahwa metode mengajar semacam itu mengandung banyak kelemahan, tetapi karena mereka tidak berdaya, maka mereka harus menerapkannya, toh mereka hanya menuruti perintah atasan. Lagi pula guru tidak mau ambil risiko, misalnya tidak menjalankan instruksi yang sudah dipatok oleh ketentuan birokrasi.

Mengenai seting kelas pun musti seragam. Di mana pun, susunan bangku di ruang kelas formasinya tetap seragam dan konvensional yaitu susunan simetris berjajar urut menyamping, dan sementara meja guru di depan. Tidak ada informasi bangku sekolah yang membentuk setengah lingkaran, atau melingkar, dan berkelom- pok-kelompok. Padalah formasi bangku seperti ini mengkondisikan murid berani bertanya dan mengungkapkan pendapat. Karena itu tidak perlu heran jika sering disinyalir bahwa murid sekarang ada kecenderungan takut bertanya. Mengapa demikian? Karena seting ruang kelasnya saja tetap konvensional yang tidak mengkondisikan murid berani bertanya.

Sadar atau tidak pola pembangunan yang selama ini kita jalankan, sesungguhnya juga menghembuskan arus penyeragaman. Mulai dari Pak Lurah hingga Pak Gubernur, suka sekali menganjurkan bentuk pagar di pinggir jalan, tugu, tulisan di atas genteng rumah penduduk, warna cat, dan lain-lain mesti seragam.

Satu indikator lagi yang menunjukkan bahwa siswa di sekolah pinggiran kurang menyukai tantangan adalah relatif rendahnya minat siswa untuk mengikuti kegiatan cerdas cermat. Aktivitas mengikuti lomba merupakan arena untuk menguji nyali dan keberanian siswa menghadapi berbagai tantangan pertanyaan secara cepat yang memerlukan jawaban secara cepat dan akurat pula. Di samping menguji aspek kecerdasan forum semacam itu juga menguji keluasan wawasan siswa. Karena sifatnya perlombaan, maka senantiasa diselenggarakan di depan umum, sehingga unsur menantangnya semakin tinggi oleh karena itu forum cerdas cermat adalah ajang atau arena yang penuh tantangan. Tabel berikut ini menunjukkan gambaran seberapa besar minat siswa di sekolah pinggiran terhadap kegiatan cerdas cermat.

Tabel 3. Grafik KetertarikanterhadapLomba Cerdas Cermat

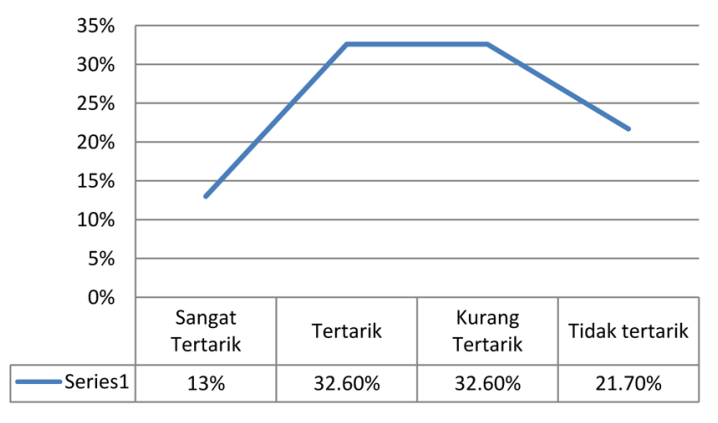


Tabel 3 memberikan gambaran bahwa siswa rata-rata kurang berminat terhadap aktivitas cerdas cermat. Hanya 13 persen yang menyatakan sangat tertarik, 32,6 persen mengaku cukup tertarik. Sementara itu yang menyatakan kurang tertarik juga 32,6 persen, dan 21,7 persen yang terang-terangan mengaku sama sekali tidak tertarik. Memang masih perlu digali apa di balik jawaban siswa tersebut, tetapi satu hal yang jelas adalah bahwa seharusnya siswa yang aktif, ketertarikan terhadap forum belajar yang menantang adalah sebuah keharusan. Apa pun kemampuan siswa, sudah sejak awal dibiasakan berada dlam forum adu cepat, adu ketangkasan berpikir, dan adu argumen. Setidaknya siswa di mana pun, jika sudah berpengalaman dalam belajar di sekolah, harus memiliki keberanian tampil di forum. Atau dengan kata lain, kemampuan berpikir cepat dan cermat, serta keberanian tampil di depan umum merupakan sesuatu yang wajar melekat dalam karakter siswa.

\section{Kemandirian Belajar}

Karakter mandiri belajar adalah sikap penting yang mesti dimiliki oleh siswa, jika ingin antusiasme belajar tetap terjaga. Antusiasme adalah kondisi konstan spirit belajar yang terus menyala-nyala dalam diri siswa. Jika siswa memiliki antusiasme dalam belajar maka ia akan terus memiliki semangat belajar tinggi dan rasa keingintahuan yang tiada henti. Hasrat belajar dan keingintahuan abadi adalah roh dan jiwa yang tumbuh terpelihara dalam diri siswa yang beretos belajar tinggi. Sayangnya siswa di sekolah pinggiran kurang memiliki karakter ini sebagaimana tampak dalam Gambar 4.

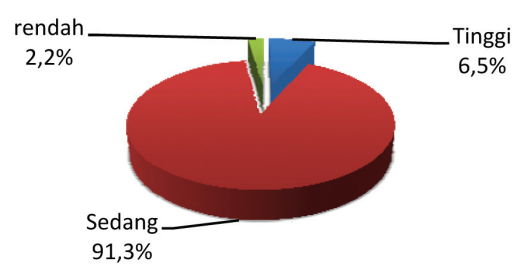

Gambar 4. Kemandirian belajar
Memperhatikan muatan yang terkandung dalam informasi tabel di atas memperlihatkan bahwa tingkat kemandirian siswa sekolah di daerah pinggiran lebih dominan berada dalam kategori sedangsedang saja, atau persentasenya 91,3 persen. Sedangkan kategori tinggi hanya 6,5 persen, sementara kategori rendah 2,2 persen. Sikap mereka ketika mendapatkan masalah atau persoalan belajar yang sulit dipecahkan rata-rata mereka meminta bantuan pada orang lain. Secara rinci gambaran ini tercermin pada jawaban mereka atas sejumlah pertanyaan yang berkaitan dengan kesulitan menghadapi persoalan sulit dalam proses belajar. Hanya 4,3 persen yang mengaku selalu mengatasi sendiri ketika menghadapi kesulitan dalam belajar. Sementara itu sebanyak 91,3 persen mengaku meminta bantuan pada orang lain ketika menghadapi masalah belajar.

Kurangnya kemandirian belajar di kalangan siswa memang merupakan gejala umum di Indonesia. Akan tetapi di kalangan siswa sekolah di daerah pinggiran situasinya lebih fenomenal boleh jadi berkaitan dengan karakter sosio-kulturalnya. Sebagian besar daerah pinggiran merupakan daerah pedesaan yang memiliki sifat komunal. Meminjam istilah Ferdinan Tonies lebih merupakan karakter gemainschaf, atau sebuah masyarakat yang memiliki ikatan emosional dan hubungan sosial yang lebih erat di antara warganya (Horstmann \& Wadley, 2006:101). Oleh karena itu semangat berbagi rasa ketika menghadapi masalah terasa tinggi ketimbang masyarakat urban yang cenderung individualistik. Nilai komunalisme ini juga mendasari ketika berhadapan dengan persoalan hidup keseharian yang cenderung distributif. Artinya ketika dalam keadaan memperoleh rejeki juga cenderung dibagi-bagi, dan begitu pula ketika sedang menghadapi kesulitan. Oleh karena itu ketika berada dalam sistuasi miskin pun kemiskinan itu juga didistribusikan. Jadi 
dalam masyarakat komunal cenderung membagi kemiskinan. Berkembang perasaan yang enak sekalipun dalam keadaan miskin, asal sama-sama. Miskin tidak apaapa asal bersama-sama.

Dengan demikian tidaklah mengherankan apabila di kalangan siswa daerah pinggiran tingkat kemandiriann belajarnya rendah, karena merupakan manifestasi dari karakter kultur komunalisme. Keadaan juga bisa dijelaskan mengapa ketika UN pencapaiannya lebih tinggi di daerah pedesaan daripada di daerah perkotaan. Akan tetapi apakah kadar representasi aktivitasnya dapat dipertanggungjawabkan? Apabila mempertimbangkan faktor sosiokultural, pastilah ada yang tidak beres dengan hasil UN tersebut.

Sebagaimana diketahui, pemerintah telah menetapkan angka 5,26 sebagai standar kelulusan bagi siswa di tingkat sekolah dasar sampai SMA bagi setiap mata pelajaran yang ditetapkan sebagai mata ujian nasional. Tetapi model evaluasi ini masih mengundang pro-kontra, dan dipertanyakan kadar representativitasnya. Pernyataan mendasar pun kemudian mengiringi keraguan terhadap kadar representativitas Ujian Nasional sebagai alat seleksi. Ada beberapa argumen yang melatarbelakangi pertanyaan tersebut.

Pertama, selama ini sudah berkali-kali muncul kasus manipulasi Ujian Nasional. Bukan saja para orangtua yang mengkondisikan terjadinya manipulasi angka Ujian Nasional, tetapi juga di kalangan guru dan sekolah. Ini dapat dimengerti karena kondisi guru dan sekolah ditentukan pula oleh pencapaian murid dalam Ujian Nasional. Akibatnya, demi menjaga "nama baik" guru dan sekolah maka mereka pun melanggar etika profesi.

Secara sosiologis, dalam masyarakat kita masih belum berkembang suatu sistem apresiasi sosial yang proporsional dan adil dalam melihat karya kegiatan, karya cipta, dan karya peradaban. Masyarakat masih kurang menghargai yang rumit-rumit, kurang menghargai pekerja keras, tetapi lebih menghargai yang entheng-entheng dan verbalistik. Di samping itu, komunalisme di mana relasi-relasi sosial masih bersifat emosional, sering disalahgunakan pada sesuatu yang seharusnya secara obyektif dan rasional. Bahkan kearifan lokal, seperti sikap welas asih, ora tegelan, masih dibawa-bawa masuk ke kawasan obyektif rasional, sehingga tidak profesional. Kaena itu ujian nasional pun harus dilakukan dua kali, karena ndak mesake masyarakat atau ora tega.

Kedua, menggunakan Ujian Nasional sebagai variabel utama untuk menyeleksi murid kurang adil dan kurang demokratis. Secara sosiologis kebijakan Ujian Nasional, yang paling dirugikan adalah anak dari kelas bawah, karena sudah kalah dalam seleksi sosial-ekonominya. Lebih dari itu Ujian Nasional hanyalah potret sesaat yang tidak menggambarkan kemampuan riil anak. Karena itu kurang adil kalau potret sesaat itu dijadikan sebagai pertaruhan masa depan anak. Ujian Nasional mencerminkan bahwa kebijakan pemerintah masih lebih memperhatikan hasil daripada sebuah proses.

Secara kultural masyarakat kita memang masih berorientasi hasil, dan kurang menghargai proses. Dalam mengevaluasi apa pun kurang memperhatikan proses suatu kegiatan, tetapi hanya dilihat dari hasilnya. "jangan meniru sesuatu dari jadinya, tapi tirulah suatu itu dari proses menjadinya". Prinsip ini belum dipakai dalam kegiatan evaluasi oleh masyarakat kita, termasuk dunia pendidikannya. Karena itu mentalitas menerabas masih berkembang subur, apa-apa ingin serba cepat dapat hasilnya dan cepat mapan.

Tingkat rendahnya kemandirian dalam belajar ini tersebut semakin terasa karena ternyata pararel dengan kecenderungan untuk mengerjakan beban belajar secara bersama. Kecenderungan ini berarti semakin menegaskan bahwa basis komunalisme memberikan fungsi atau pengaruh 
terhadap rendahnya kemandirian. Ketika ditanya apakah dalam setiap ada kegiatan ada keinginan bergabung secara tim, responden yang menyatakan sangat ingin bergabung ada 30,4 persen, yang mengaku ingin bergabung 45,7 persen, menunggu disuruh untuk bergabung sebanyak 13,0 persen, dan hanya 8,7 persen yang mengaku kurang tertarik bergabung.

Tabel 4. Grafik Keinginan Bergabung dalam Tim

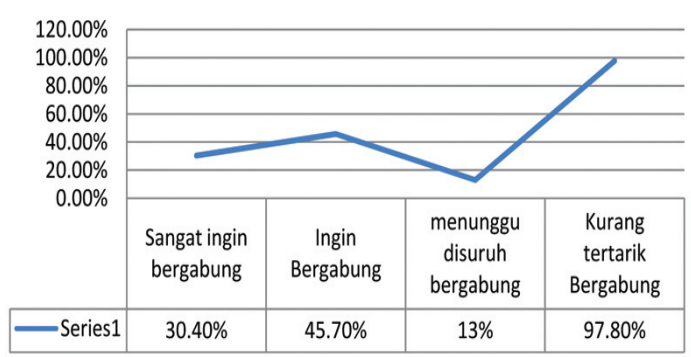

Siswa pun juga mengaku memiliki kelompok belajar, yaitu sebanyak 34,8 persen, memiliki kelompok belajar tetapi tidak kurang aktif sebanyak 30,4 persen, dan 34,8 persen mengaku tidak memiliki kelompok belajar. Ketika ditanya bagaimana intensitas berhubungan dengan teman ketika melakukan aktivitas belajar sehari-hari, responden yang mengaku sering sekali 21,7 persen, sering 28,3 persen, kadangkadang 37,0 persen, dan hanya 10,9 persen yang mengaku tidak pernah berhubungan dengan teman.

Tabel 5. Grafik Memiliki Kelompok Belajar

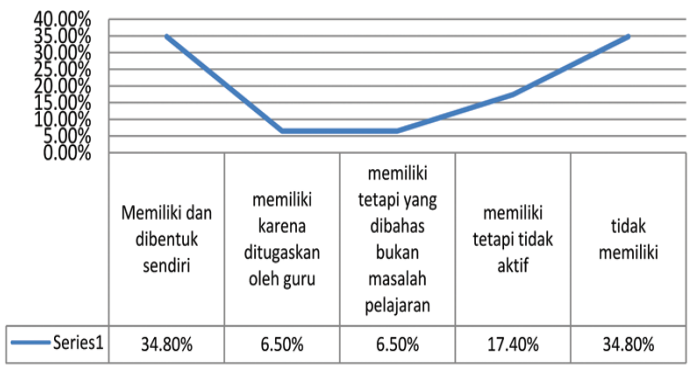

Data tersebut mengindikasikan bahwa siswa sekolah di daerah pinggiran aktivitas belajarnya masih bersifat komunal. Secara sederhana kecenderungan tersebut dapat dikatakan bahwa komunalisme menyebabkan sifat kemandirian kurang berkembang dalam diri siswa. Mereka lebih suka mengerjakan pekerjaan rumah secara berkelompok, karena berharap dapat meminta bantuan pada temannya yang bisa. Seperti biasa, dalam belajar kelompok sesungguhnya kurang efektif jika dilihat dari hasil per individu, karena biasanya yang mengerjakan praktis hanya siswa yang pandai. Inilah yang menjadi embrio berkembangnya budaya titip nama, meskipun secara individual mereka tidak terlibat dalam kerja kelompok. Belum lagi jika dilihat dari efektivitas dan intensitas penyerapan pengetahuannya. Kebanyakan ketika belajar kelompok, lebih banyak ngobrolnya daripada belajarnya. Lebih dari itu, ketertarikan siswa terhadap belajar kelompok lebih didorong oleh aspek rekreatifnya daripada motif keingintahuan dan penyelesaian masalahnya. Jadi tingginya dorongan belajar kelompok berbading lurus dengan karakter masyarakat komunal yang gemar bergerombol dan berkumpul. Kecenderungan seperti itu sering kali tidak ada hubungannya dengan peningkatan kemampuan belajar, sehingga dapat dikatakan bahwa komunalisme kurang memiliki konstribusi terhadap berkembangnya etos belajar di kalangan siswa.

Hasil analisis tabulasi silang menginformasikan gejala menarik di seputar isu pendidikan sekolah daerah pinggiran. Beberapa asumsi yang dibangun sebelumnya terbukti benar adanya, meskipun ada pula asumsi yang kurang sesuai dengan fakta di lapangan. Sebagai ilustrasi misalnya, bahwa etos belajar siswa pada sekolah pinggiran relatif rendah, sebagian besar data menunjukkan dukungan terhadap asumsi tersebut. Sebagaimana ditunjukkan dalam hasil penelitian ini, rata-rata tingkat etos belajar siswa di sekolah pinggiran 
terbukti rendah atau cenderung sedang. Ketika dipersilangkan dengan variabel asal daerah, hasilnya menunjukkan bahwa siswa yang tinggal di daerah pinggiran terbukti memiliki etos belajar pada tingkat sedang cenderung rendah. Bahkan jika dilihat dari aspek teritori menunjukkan adanya kecenderunan bahwa semakin ke wilayah pinggiran, siswanya semakin rendah etos belajarnya sebagaimana tampak dalam Tabel 6.

Tabel 6. Hubungan Asal Daerah dan Etos Belajar Siswa

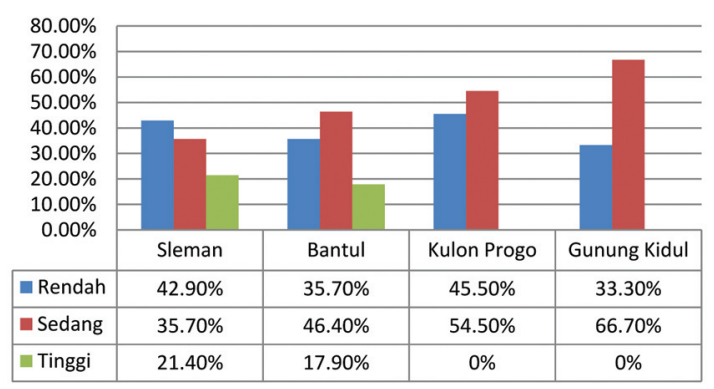

Memperhatikan Tabel 6 menginformasikan adanya peta etos belajar siswa di daerah pinggiran. Posisi etos belajar rendah secara berturut-turut diduduki oleh Kulon Progo 45,5 persen; Sleman 42,9 persen; Bantul 35,7 persen; dan Gunung Kidul. Sebagaimana diketahui jika titik sentralnya adalah Keraton Yogyakarta, maka secara teritori Kulon Progo merupakan wilayah yang paling pinggir. Jarak kewilayahan, jika diukur dari kilometer nol ada di Tugu perempatan Jalan Mangkubumi, maka batas Kulon Progo memang yang paling jauh. Dalam data tersebut Gunung Kidul etos belajar siswanya persentase kerendahannya memang paling kecil, tetapi oleh karena lokasi penelitiannya berada di Piyungan, maka termasuk kategori sekolah yang dekat dengan pusat Keraton.

Namun demikian, data di atas menunjukkan bahwa persentase etos kerja tinggi, kedua daerah pinggiran, yaitu Kulon Progo dan Gunung Kidul persentasenya nol. Sementara Sleman kategori etos belajar tinggi 21,4 persen; dan disusul Bantul 17,9 persen. Jadi data tersebut membuktikan bahwa tingginya etos belajar berkaitan dengan jauh-dekatnya dengan pusat pemerintahan di Yogyakarta. Artinya ada kecenderungan bahwa semakin dekat dengan pusat, ada kecenderungan persentase etos belajar tinggi semakin besar. Meskipun penelitian ini tidak membandingkan dengan sekolah di daerah pusat kota Yogyakarta, tetapi mengkomparasikan dengan sesama daerah pinggiran tersebut, hasil peringkat etos belajarnya menunjukkan signifikansi dengan jauh dekatnya dengan pusat pemerintahan. Kecenderungan tersebut boleh jadi merupakan konsekuensi logis dari model kekuasaan Jawa yang bersifat konsentris. Sudah sejak lama, bahwa pemusatan kekuasaan juga diikuti oleh pemusatan fasilitas publik dengan derajat kualitas yang lebih baik di pusat ketimbang di pinggiran. Lebih dari itu, berbagai sumber daya, termasuk sumber daya manusia, secara kualitas memang lebih baik yang berada di seputar pusat pemerintahan. Oleh karena itu, sekolahsekolah di daerah pusat secara umum memang lebih memiliki fasilitas dan sumber daya yang lebih baik, jika dibandingkan dengan sekolah di daerah pinggiran.

Akan tetapi pengertian pinggir di sini bukan saja dari aspek teritori, tetapi juga dari aspek sosiologis. Karena itu dalam penelitian ini juga melihat bagaimana tingkat etos belajar siswa dilihat dari variabel status sosial. Tesis yang dikemukakan adalah bahwa semakin tinggi etos tingkat status sosial, semakin tinggi tingkat etos belajarnya. Hanya saja karena penelitian ini tidak membandingkan dengan sekolah di daerah pusat, sehingga hanya membandingkan dengan sesama sekolah di daerah pinggiran. Hasilnya menunjukkan bahwa meskipun status sosialnya tinggi, tetapi tetap saja etos belajarnya masuk kategori rendah, sebagaimana dapat diperiksa dalam Tabel 7. 
Tabel 7. Hubungan Status Sosial dan Status Belajar

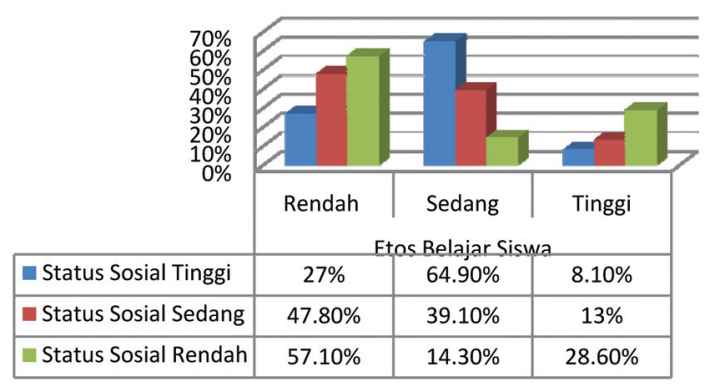

Data dalam Tabel 7 menunjukkan bahwa oleh karena etos belajar rata-rata responden di daerah pinggiran memang rendah, maka sekalipun yang masuk dalam kategori status sosial tinggi, tetap saja etos belajarnya cenderung rendah. Sebagaimana tampak dalam tabel di atas, responden yang berstatus sosial tinggi, tingkat etos belajarnya 27,0 persen kategori rendah, 64,9 persen sedang, dan hanya 8,1 persen yang berkategori etos belajar tinggi. Sementara yang memiliki status sosial rendah dan memiliki etos belajar rendah mencapai 57,1 persen. Dengan demikian dalam masyarakat pinggiran, status sosial kurang memberikan dampak signifikan terhadap tinggi-rendahnya etos belajar siswa. Jadi siswa di kalangan sekolah pinggiran, etos kerjanya memang cenderung rendah, sekalipun mereka berasal dari kalangan keluarga berstatus sosial relatif tinggi.

Fakta semacam itu dapat dijelaskan bahwa faktor lingkungan sosial lebih menentukan. Sebagaimana karakteristik masyarakat komunal dan agrarian, suasana kompetitif kurang tercipta, orang cenderung berusaha untuk menjaga kerukunan dan keharmonisan sosial. Rendahnya kompetisi belajar inilah yang membuat etos belajar juga kurang tinggi. Dorongan untuk meraih prestasi belajar pun juga kurang terpacu, karena tidak adanya suasana yang menantang. Oleh karena itu, banyak keluarga yang agak mampu di daerah pinggiran lebih suka menyekolah- kan anaknya di daerah perkotaan dengan harapan agar mendapatkan tantangan belajar yang berat dan kompetitif. Di kalangan masyarakat pinggiran sering berkembang persepsi, bahwa ukuran prestasi di sekolah pinggiran berbeda dengan sekolah di daerah perkotaan. Misalnya muncul dalam ungkapan, "ya kalau untuk ukuran di desa, anak itu sudah bagus, tetapi jangan dibandingkan dengan prestasi anak sekolah di perkotaan". Ungkapan ini menunjukkan bahwa telah berkembang perasaan loser atau sudah kalah jika dibandingkan dengan anak di pusat perkotaan.

Akan tetapi dalam penelitian ini menemukan data menarik di seputar pandangan terhadap aktivitas belajar. Secara umum responden memiliki pandangan yang positif terhadap aktivitas belajar. Hampir semua responden atau sebanyak 93,5 persen mengatakan bahwa bersekolah karena ingin meraih cita-cita hidup yang lebih baik. Sementara itu, pandangan mereka terhadap belajar juga positif, yaitu 56,5 persen mengaku bahwa belajar merupakan suatu aktivitas yang menyenangkan, dan yang mengaku belajar adalah aktivitas belajar menyenangkan tetapi terasa berat 39,1 persen. Hanya 2,2 persen yang memandang bahwa belajar merupakan suatu yang besar dan membebani hidup. Juga ketika mereka ditanya tentang aktivitas membaca, mereka yang mengaku bahwa membaca merupakan suatu yang menyenangkan 54,3 persen; suatu yang menyenangkan tetapi terasa berat sebanyak 26,1 persen. Mereka yang mengaku bahwa membaca merupakan aktivitas yang kurang menyenangkan 15,2 persen; dan 4,3 persen yang mengaku bahwa membaca merupakan beban hidup.

Ironisnya, persepsi terhadap aktivitas belajar yang positif itu tidak berbanding lurus dengan upaya yang dilakukan dalam praksis belajarnya. Gambaran paradoksal ini dapat dilihat dalam Tabel 8. 
Tabel 8. Hubungan Persepsi terhadap Aktivitas Belajar dan Etos Belajar

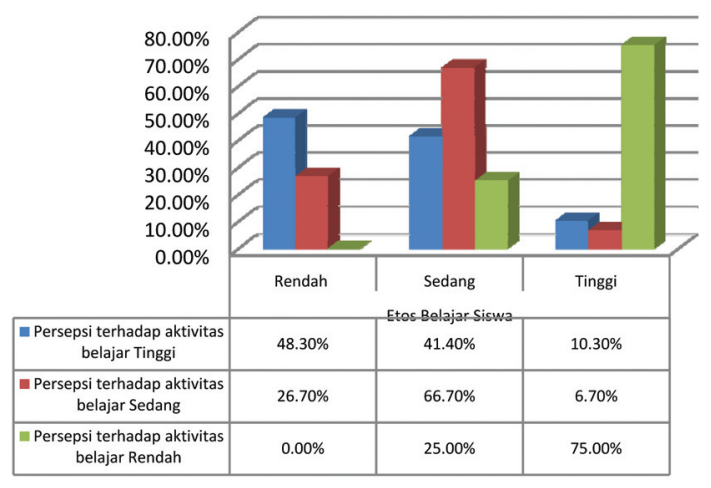

Tabel 8 terlihat hubungan paradoksal antara persepsi akvitas belajar terhadap etos belajar. Artinya, tidak ada hubungan yang bersifat pararel atau liniaritas antara persepsi positif terhadap belajar dengan tingginya etos belajar. Sebagaimana tampak dalam Tabel 8, responden yang memiliki persepsi positif atau tinggi, ternyata etos belajarnya rendah, yaitu 48,3 persen; kategori etos belajar sedang 41,4 persen; dan yang beretos belajar tinggi hanya 10,3 persen. Sedangkan persepsi terhadap belajar kategori sedang, tetapi beretos belajar rendah mencapai 26,7 persen; kategori sedang 66,7 persen; dan beretos belajar tinggi hanya 6,7 persen. Total hubungan antara persepsi terhadap belajar dengan etos belajar menunjukkan kategori rendah 39,1 persen; etos belajar kategori sedang 48,9 persen; dan hanya 12 persen kategori tinggi.

\section{PENUTUP}

Etos belajar siswa sekolah di daerah pinggiran ternyata masih dalam kategori sedang cenderung rendah. Indikatornya adalah bahwa di kalangan siswa sekolah pinggiran ditandai rendahnya minat baca, kurang menyukai tantangan atau rendahnya watak kompetiti, rendahnya kemandirian, tanggung jawab belajar yang tidak tinggi. Letak teritorial cenderung memiliki hubungan signifikan terhadap rendahnya etos belajar siswa di sekolah pinggiran.
SMA di daerah Kabupaten Kulon Progo dan Gunung Kidul cenderung memiliki etos belajar lebih rendah daripada yang di Bantul, dan Sleman, karena dua daerah tersebut memiliki jarak lebih jauh terhadap pusat kota Yogyakarta. Secara sosiologis, mereka yang berstatus sosial rendah, berbanding lurus dengan etos belajarnya. Artinya, siswa yang berasal dari kalangan status sosial rendah, etos belajarnya cenderung tidak tinggi.

Terdapat hubungan yang tidak linier antara persepsi positif terhadap belajar dengan praksis belajar di kalangan siswa sekolah daerah pinggiran. Fakta kontradiktif tersebut menunjukkan bahwa karakter inkonsistensi antara apa yang diucapkan dengan apa yang terjadi dalam praksis cenderung bertolak belakang. Artinya, antara kemauan dengan upaya yang dilakukan tidak senantiasa berbanding lurus. Siswa yang memiliki pandangan positif terhadap belajar, atau mengaku senang terhadap aktivitas belajar dan membaca, serta memiliki harapan besar atau cita-cita besar melalui sekolah, ternyata tidak diimbangi secara cukup meyakinkan dengan usaha nyata dalam kegiatan belajarnya. Dengan kata lain, keinginan siswa sekolah pinggiran besar, tetapi tidak diikuti oleh usaha keras dalam belajarnya untuk meraih apa yang dicitacitakan tersebut.

Fenomena tersebut mengindikasikan adanya salah tempat atau displacement. Artinya, kultur komunal-agrarian berada dalam tempat di mana arus moda kapitalisme yang menuntut persaingan ketat. Dengan demikian dapat ditemukan jawaban bahwa harapan besar terhadap aktivitas bersekolah tidak diikuti oleh usaha yang produktif. Boleh jadi ini juga merupakan implikasi logis dari masyarakat di Indonesia pada umumnya ketika menghadapi arus modernisasi yang bermoda kapitalisme. Di mana kultur agrarisnya tetap bertahan, tetapi berada dalam moda produksi kapitalisme. Akibatnya yang 
berkembang konsumerisme, sementara watak produktifnya tidak berkembang. Perubahan bentuk struktural yang bersifat modern-kapitalistik ternyata tidak diikuti oleh transformasi kultural, dari moderntradisional ke arah modern-kapitalistik. Salah satu watak kultur kapitalistik adalah semangat kompetisi dan efisiensi, dan watak inilah yang tidak berkembang dalam siswa sekolah di daerah pinggiran yang agrarian-tradisional.
DAFTAR PUSTAKA

Dede Rosyada. (2004). Paradigma Pendidikan Demokratis: Sebuah Pelibatan Masyarakat dalam Penyelenggaran Pendidikan. Jakarta: Prenada Media.

Horstmann, Alexander dan Reed L. Wadley. (2006). Centering the Margin: Agency and Narative in Southeast Asian Borderlands. New York: Berghahn Books.

Kochhar, S.K. (1967). Methods and Techniques of Teaching. New Delhi: Sterling Publishers. 